\title{
KELUHAN PENDENGARAN DAN PEMETAAN KEBISINGAN PADA INDUSTRI PENGGERGAJIAN KAYU UD. MAYOA KABUPATEN JEMBER
}

\section{HEARING COMPLAINTS AND NOISE MAPPING AT UD. MAYOA TIMBER SAWMILL INDUSTRY IN JEMBER DISTRICT}

\author{
Reny Indrayani ${ }^{1 *}$, Karera Aryatika ${ }^{2}$ \\ ${ }^{1}$ Program Studi Ilmu Kesehatan Masyarakat, Fakultas Keshatan Masyarakat, Universitas Jember, \\ Jl. Kalimantan no.37 68121 Jember, Jawa Timur, Indonesia \\ ${ }^{2}$ Program Studi Ilmu Gizi, Fakultas Kesehatan Masyarakat Kampus Bondowoso, Selatan Sawah, \\ Poncogati, Curah Dami, 68251, Kabupaten Bondowoso, Jawa Timur, Indonesia \\ *email: renyindrayani.fkm@unej.ac.id
}

\begin{abstract}
Many study revealed that hearing complaints correlated positively with the hearing loss. Hearing loss is the fourth highest cause of disability in the world and can be caused by exposure to noise in the workplace. Many studies reveal that one of the occupational sectors with a high noise level in the work area is wood processing. WHO recommends identifying hearing loss and its causes, and implementing preventive measures to limit the adverse effects caused by noise exposure. The purpose of this study was to describe the hearing complaints experienced by workers and to map the noise intensity at the UD. Mayoa Jember to determine the type of ear protection equipment needed by workers. This research was a descriptive research. The data used in this study are primary data obtained through interviews and observations. Interviews were conducted with all workers totaling 32 people. Observations were made by measuring the noise intensity at 139 measurement points scattered throughout the work area. The data processing for making noise distribution maps is done with the help of the Surfer ver.16 application. The results showed that most respondents experienced hearing complaints at a level that did not interfere with their activities. The noise intensity mapping shows that the noise that occurs during working hours ranges from 73.8 - $105.2 \mathrm{dBA}$ and the area with a noise level above TLV is around 500 $m 2$. The intensity during rest hours ranges from 68.2 - $101.0 \mathrm{dBA}$ with an area with a noise level above $T L V$ is less than $30 \mathrm{~m} 2$. The recommended APT for noise levels of $86-95 \mathrm{dBA}$ is ear plugs, for noise 96 - 100 dBA is ear plugs / earmuffs, while for noise more than 100 dBA is dual protection, namely ear plugs and earmuffs. Suggestions that can be given to business managers are to redesign working hours or make work rotations.
\end{abstract}

Keywords: hearing complaints, noise mapping, hearing protection devices, sawmills.

\begin{abstract}
Abstrak
Keluhan pendengaran, menurut banyak penelitian telah dinyatakan berkorelasi positif dengan kehilangan pendengaran. Kehilangan pendengaran merupakan penyebab kecacatan keempat tertinggi di dunia dan dapat disebabkan oleh paparan kebisingan di tempat kerja. Banyak penelitian mengungkapkan bahwa salah satu sektor pekerjaan dengan tingkat kebisingan tinggi di area kerjanya adalah pengolahan kayu. WHO merekomendasikan adanya tindakan identifikasi gangguan pendengaran beserta penyebabnya, dan menerapkan tindakan pencegahan untuk membatasi dampak merugikan yang ditimbulkan oleh paparan kebisingan. Tujuan dari penelitian ini adalah untuk menggambarkan keluhan pendengaran yang dialami pekerja dan memetakan intensitas kebisingan di tempat kerja industri penggergajian kayu UD. Mayoa Jember guna menentukan jenis alat pelindung telingan / pendengaran yang dibutuhkan oleh pekerja. Penelitian ini merupakan penelitian deskriptif. Data yang digunakan dalam penelitian ini merupakan data primer yang didapatkan melalui wawancara dan observasi.
\end{abstract}


Wawancara dilakukan kepada seluruh pekerja yang berjumlah 32 orang. Observasi dilakukan dengan melakukan pengukuran intensitas kebisingan pada 139 titik pengukuran yang tersebar di seluruh area kerja. Pengolahan data untuk pembuatan peta sebaran kebisingan dilakukan dengan bantuan aplikasi Surfer ver.16. Hasil penelitian menunjukkan bahwa sebagian besar responden mengalami keluhan pendengaran pada level yang tidak mengganggu aktifitas. Pemetaan intensitas kebisingan menunjukkan bahwa kebisingan yang terjadi pada saat jam kerja berkisar antara 73,8 - 105,2 dBA dan luas area dengan tingkat kebisingan di atas NAB adalah sekitar $500 \mathrm{~m}^{2}$. Intensitas pada saat jam istirahat berkisar antara 68,2-101,0 dBA dengan luas area dengan tingkat kebisingan di atas NAB adalah kurang dari 30 $\mathrm{m}^{2}$. APT yang direkomendasikan untuk tingkat kebisingan $86-95 \mathrm{dBA}$ adalah sumbat telinga, untuk kebisingan 96-100 dBA adalah sumbat telinga/penutup telinga, sedangkan untuk kebisingan lebih dari $100 \mathrm{dBA}$ adalah perlindungan ganda yakni sumbat telinga dan penutup telinga. Saran yang dapat diberikan kepada pengurus usaha adalah untuk melakuan redesain jam kerja atau melakukan rotasi kerja. Kata kunci: keluhan pendengaran, pemetaan kebisingan, alat pelindung pendengaran, penggergajian kayu.

\section{PENDAHULUAN}

Keluhan pendengaran pada banyak penelitian telah terbukti berhubungan dengan kejadian kehilangan pendengaran. Hasil Penelitian Samelli, dkk (2013) mengungkapkan bahwa keluhan pendengaran berkorelasi positif dengan tipe kehilangan pendengaran, dan dapat digunakan sebagai faktor prediktif kehilangan pendengaran. Kehilangan pendengaran merupakan penyebab kecatatan keempat tertinggi di dunia, dengan perkiraan biaya tahunan lebih dari 750 miliar dolar. Pada tahun 2018, secara global diperkirakan terdapat sekitar 466 juta orang yang mengalami gangguan pendengaran. Apabila kondisi ini tidak dikendalikan, maka WHO memproyeksikan akan ada 630 juta orang yang hidup dengan gangguan pendengaran pada tahun 2030 dan akan meningkat menjadi lebih dari 900 juta orang pada tahun 2050 (WHO, 2018). Kehilangan pendengaran dapat disebabkan oleh paparan kebisingan (NIHL) di tempat kerja dan hal ini juga menjadi masalah kesehatan yang konsekuensinya signifikan bagi perekonomian (Lie, 2016).

Banyak penelitian mengungkapkan bahwa salah satu sektor pekerjaan dengan tingkat kebisingan tinggi di area kerjanya adalah pengolahan kayu (Zheng dkk, 2020). Sebuah survei di India menunjukkan bahwa $28 \%$ pekerja penggergajian menderita NIHL (Dhere dkk, 2009). Sebuah studi cross-sectional Nepal menunjukkan bahwa $31 \%$ tukang kayu dan $44 \%$ penggergajian memenuhi kriteria untuk NIHL, dan tingkat kebisingan berkisar antara 71,2 hingga 93,9 dBA (Robinson dkk, 2015). Di Indonesia, salah satu studi pada industri pengolahan kayu menunjukkan bahwa tingkat kebisingan yang dihasilkan di area kerja berada diantara 65,9 sampai dengan 91,5 dBA. Intensitas kebisingan tertinggi ditemukan pada area penggergajian kayu (Gani dkk, 2018).

Tingginya jumlah penderita gangguan pendengaran akibat paparan kebisingan, tentunya menimbulkan kekhawatiran. Oleh sebab itu, WHO merekomendasikan adanya tindakan identifikasi gangguan pendengaran beserta penyebabnya, dan menerapkan tindakan pencegahan untuk membatasi dampak merugikan yang ditimbulkan oleh paparan kebisingan (WHO, 2018). Sebelum melaksanakan pengendalian kebisingan, terlebih dahulu harus diketahui intensitas kebisingan dan bagaimana sebaran kebisingan di area kerja. Hal ini dapat diketahui melalui pemetaan intensitas kebisingan di tempat kerja.

Pemetaan kebisingan di industri sangat berguna untuk menilai risiko kebisingan. Analisis terhadap peta kebisingan dapat digunkana pengurus suatu industri untuk mengambil kebijakan pengendalian kebisingan di tempat kerjanya. Misalnya digunakan sebagai pertimbangan dalam pemilihan alat pelindung telinga (APT). Pemetaan kebisingan di tempat kerja juga dapat meningkatkan kesadaran pekerja mengenai risiko paparan kebisingan sehingga dalam jangka panjang mampu mengurangi biaya yang dikeluarkan untuk penyakit akibat kerja (Platon dan Hionis, 2014).

UD. Mayoa adalah sebuah industri pemotongan kayu skala menengah yang berlokasi di Kabupaten Jember. UD. Rata-rata volume produksi UD. Mayoa dalam sehari adalah $\pm 30 \mathrm{~m} 3$ potongan kayu yang selanjutnya dipasarkan ke industri pengolahan kayu di dalam maupun luar Provinsi Jawa Timur (Fahlefi, 2020). Proses produksi yakni berupa pemotongan kayu menggunakan mesin 
pemotong kayu dengan tenaga dynamo. Berdasarkan hasil studi pendahuluan diketahui bahwa intensitas kebisingan yang dihasilkan oleh mesin pemotong kayu di UD. Mayoa melampaui Nilai Ambang Batas (NAB) yang diperkenankan oleh pemerintah yakni sebesar 85 dBA. Hal tersebut tentunya berpotensi menimbulkan gangguan pendengaran. Oleh sebab itu, penelitian ini ditujukan untuk menggambarkan keluhan pendengaran yang dialami pekerja dan memetakan intensitas kebisingan di tempat kerja industri penggergajian kayu UD. Mayoa Jember guna menentukan jenis alat pelindung telingan / pendengaran yang dibutuhkan oleh pekerja.

\section{METODE PENELITIAN}

Penelitian merupakan penelitian

Deskriptif. Penelitian dilaksanakan pada Oktober 2020 berlokasi di Industri Penggergajian Kayu UD. Mayoa, Kecamatan Kalisat, Kabupaten Jember. Unit analisis dalam penelitian ini adalah area/tempat kerja UD. Mayoa dan responden penelitian adalah seluruh pekerja bagian produksi yang berjumlah 32 orang. Variabel penelitian ini adalah keluhan pendengaran, intensitas kebisingan di area kerja yang digunakan dalam pemetaan intensitas kebisingan. Dalam penelitian ini peneliti juga akan menentukan jenis alat telinga (APT) yang dibutuhkan oleh pekerja sesuai dengan paparan intensitas kebisingan yang diterima di tempat kerja. Data keluhan pendengaran merupakan data primer yang dikumpulkan melalui wawancara dengan bantuan Mackay Hearing Questionnaire. Keluhan ini bersifat subjektif sehingga keluhan yang digambarkan sesuai dengan persepsi masing-masing responden penelitian. Data tentang intensitas kebisingan merupakan data primer yang dikumpulkan melalui pengukuran intensitas kebisingan menggunakan alat sound level meter (SLM) Dekko FT-7933. Pengolahan data intensitas kebisingan menjadi peta intensitas kebisingan dilakukan dengan bantuan aplikasi Surfer ver.16.

\section{HASIL DAN PEMBAHASAN}

\section{Keluhan Pendengaran}

Hasil pengumpulan data tentang keluhan pendengaran yang dialami oleh responden ditampilkan pada tabel 1. Data yang disajikan dalam tabel 1 menunjukkan bahwa sebagian besar responden, yakni $44 \%$ responden mengalami keluhan pendengaran pada level yang tidak mengganggu aktifitas. Kendati demikian, pada tabel 1 juga didapatkan informasi bahwa terdapat 34\% responden yang mengeluhkan gangguan pendengaran pada level yang dapat mengganggu aktivitas.

Informasi yang didapatkan dari hasil wawancara pada responden menggunakan Mackay Hearing Questionnaire, menunjukkan bahwa dari 12 macam keluhan yang ditanyakan pada kuesioner tersebut, sebagian besar keluhan pendengaran yang dialami responden adalah berupa kesulitan untuk mengikuti percakapan di lingkungan yang bising (misalnya di tempattempat umum).

Tabel 1. Distribusi Frekuensi Keluhan Pendengaran Responden

\begin{tabular}{lcc}
\hline \multirow{2}{*}{ Keluhan Pendengaran } & \multicolumn{2}{c}{ Frekuensi } \\
\cline { 2 - 3 } & n & \% \\
\hline Tidak Mengalami & 7 & 22 \\
$\begin{array}{l}\text { Mengalami Gangguan Pendengaran } \\
\text { tanpa mengganggu aktivitas }\end{array}$ & 14 & 44 \\
$\begin{array}{l}\text { Mengalami Gangguan yang } \\
\text { mengganggu aktivitas }\end{array}$ & 11 & 34 \\
\hline
\end{tabular}

Hal ini dikeluhkan oleh sebanyak 53\% responden. Keluhan terbanyak kedua yang berkaitan dengan pendengaran adalah responden merasa orang-orang di sekitarnya banyak bergumam atau bicara dengan volume rendah. Hal ini dikeluhkan oleh $44 \%$ responden penelitian. Dengan kata lain, responden masih dapat mendengar suara, akan tetapi beberapa jenis suara seperti suara percakapan, terdistorsi dan menjadi sulit untuk dipahami. Hal ini seperti yang diungkapkan oleh Gokulram (2017) dalam penelitiannya. Kebisingan di tempat kerja pada awalnya akan mempengaruhi kemampuan mendengar suara dengan frekuensi tinggi (bernada tinggi). Ini berarti bahwa meskipun seseorang masih dapat mendengar beberapa suara, ucapan atau suara lainnya mungkin tidak jelas atau terdistorsi. Pekerja dengan gangguan pendengaran biasanya berkata bahwa ia dapat mendengarkan percakapan namun tidak dapat mengerti isi percakapan. Distorsi terjadi terurama saat ada suara latar atau banyak orang berbicara.

\section{Pemetaan Kebisingan di Tempat Kerja}

Pemetaan kebisingan dilakukan dengan beberapa tahapan. 1) Pembuatan peta industri dan penentuan titik pengukuran; 2) Pengukuran intensitas kebisingan; 3) Pengolahan data dengan perhitungan nilai Leq; 4) Pengolahan data menggunakan aplikasi Surfer untuk menghasilkan gambaran peta kebisingan. Dari 
hasil pengukuran area kerja diketahui bahwa UD. Mayoa berukuran 55 x $62 \mathrm{~m}\left(3.410 \mathrm{~m}^{2}\right)$. Peta industri dalam penelitian ini digambarkan dengan skala 1 : 1000. Titik pengukuran ditentukan sebanyak 134 titik. Titik pengukuran pada lingkungan kerja diambil pada setiap jarak 5 meter dan pada titik tertentu yang mewakili keberadaan pekerja pada saat jam kerja. Peta industri UD. Mayoa disertai dengan lokasi titik pengukuran kebisingan disajikan pada Gambar 1.

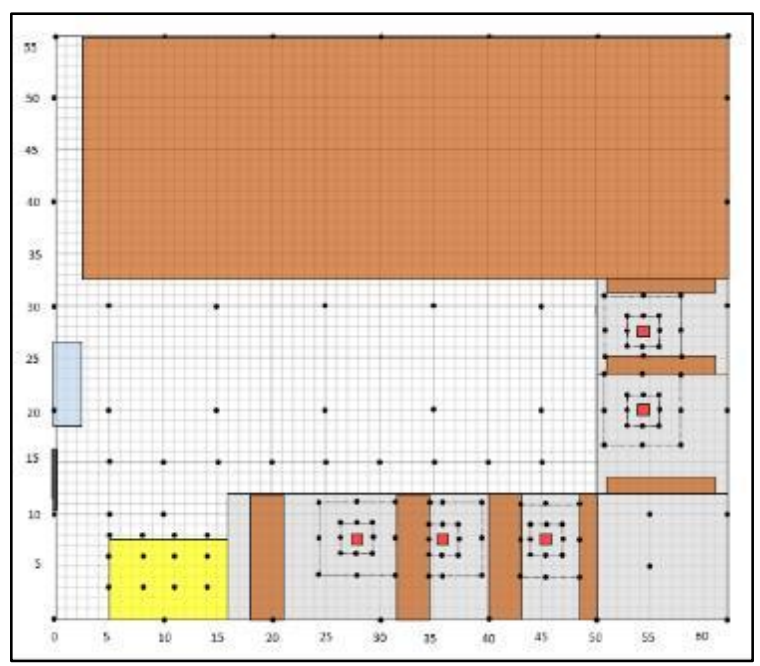

Keterangan:

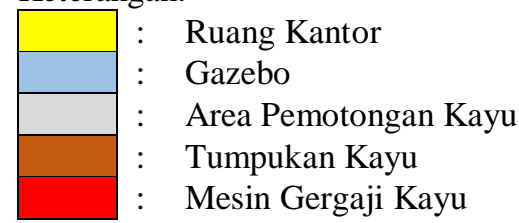

Gambar 1. Peta Industri dan Titik Pengukuran Kebisingan Di UD. Mayoa.

Pengukuran intensitas kebisingan pada penelitian ini dilakukan pada skala pembobotan A menggunakan Sound Level Meter dengan range pengukuran $30-130 \mathrm{dBA}$. Prosedur pengukuran kebisingan disesuaikan degan SNI 7231:2009 tentang Metoda Pengukuran Kebisingan di Tempat Kerja. Pengukuran dilakukan pada jam kerja dan pada jam istirahat. Pengukuran kebisingan pada jam kerja dilakukan di tengah jam kerja yakni pada pukul $10.00-11.00$ WIB. Pengukuran ini bertujuan untuk menggambarkan intensitas kebisingan yang terjadi selama mesin gergaji kayu beroperasi. Pengukuran kebisingan pada jam istirahat dilakukan pada pukul $12.00-13.00$ WIB. Pengukuran ini bertujuan untuk menunjukkan intensitas kebisingan pada saat mesin penggergajian kayu tidak beroperasi.

Pengukuran kebisingan pada setiap titik dilakukan setiap 5 detik selama 10 menit sehingga pada satu titik didapatkan 120 hasil pengukuran. Sebagaimana diatur dalam KEP48/MENLH/11/1996 tentang Baku Tingkat Kebisingan, 120 nilai intensitas kebisingan tersebut harus diolah menjadi 1 nilai tingkat kebisingan ekuivalen / Leq. Mengingat SLM yang digunakan tidak difasilitasi dengan pembacaan nilai Leq, maka nilai Leq pada setiap titik pengukuran ditentukan menggunakan persamaan :

Rumus Leq

$L e q=10 \log \left\{\frac{1}{f} 10^{0,1 L 1}+\frac{1}{f} 10^{0,1 L 2}+\ldots+\frac{1}{f} 10^{0,1 L 120}\right\}$

Keterangan :

Leq : Tingkat kebisingan ekuivalen

f : Urutan pengukuran kebisingan

L : Hasil pengukuran kebisingan ke-n

Keseluruhan nilai Leq yang didapat melalui perhitungan dengan persamaan tersebut kemudian diolah menggunakan aplikasi Surfer sehingga menghasilkan peta intensitas kebisingan yang ditampilkan pada gambar 2 (a dan b).

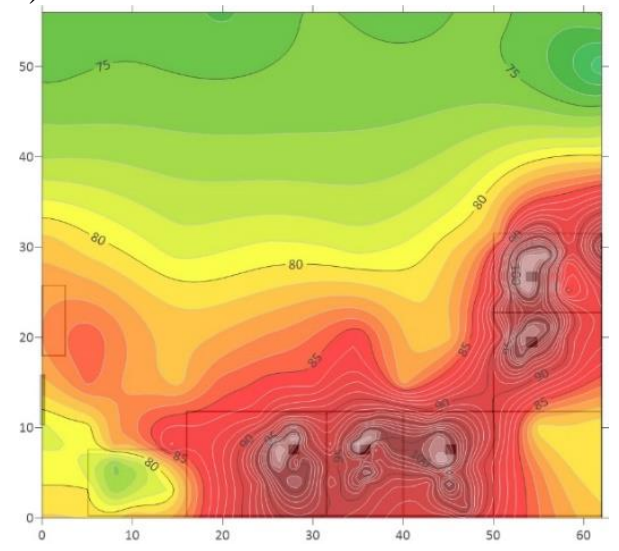

(a)

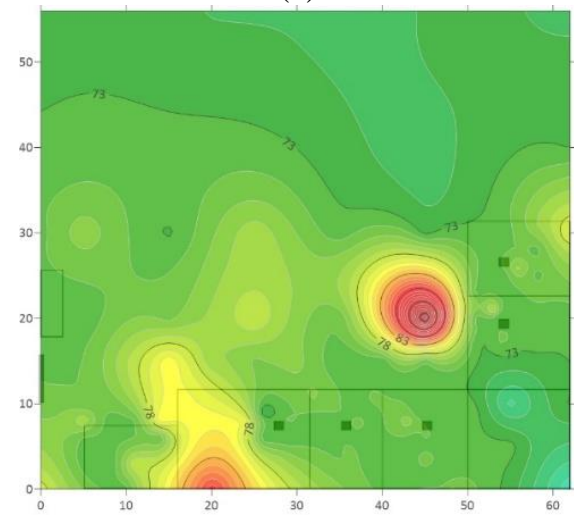

(b)

Gambar 2. (a) Peta Intensitas Kebisingan pada Saat Jam Kerja, (b) Peta Intensitas Kebisingan pada Saat Jam Istirahat 
Gambar 2 menunjukkan bahwa kebisingan dengan intensitas di atas NAB (85 dBA) diwakili dengan warna merah. Pada area ini, pekerja wajib menggunakan APT. Peta intensitas kebisingan yang ditampilkan pada kedua gambar menunjukkan bahwa kebisingan yang terjadi pada saat jam kerja dan pada saat jam istirahat berbeda secara signifikan. Area dengan intensitas kebisingan di atas NAB pada saat jam kerja lebih luas dibandingkan pada saat jam istirahat yang didominasi oleh area dengan intensitas kebisingan di bawah NAB.

Intensitas kebisingan pada saat jam kerja berkisar antara 73,8 - 105,2 dBA. Sumber kebisingan utama pada saat jam kerja adalah mesin gergaji kayu yang berjumlah 5 unit. Kebisingan di atas NAB ini terjadi di area yang beradius 5-10 meter dari mesin gergaji. Luas area dengan kebisingan di atas NAB mencapai lebih dari $500 \mathrm{~m}^{2}$. Semakin mendekati mesin penggergajian, intensitas kebisingan mengalami peningkatan. Nilai intensitas kebisingan tertinggi didapati pada jarak 1 meter dari mesin gergaji yakni tepat di lokasi pekerja yang bertugas untuk mendorong kayu ke arah mesin gergaji. Intensitas kebisingan pada industri perkayuan menurut Noweir (2015), tergantung pada jumlah dan jenis operasi mesin serta jumlah pekerja di tempat kerja, sedangkan konstruksi bangunan pabrik tidak berkontribusi signifikan terhadap intensitas kebisingan. Intensitas kebisingan yang dihasilkan oleh mesin gergaji kayu bervariasi dari 80 hingga 120 dBA. Kebisingan tertinggi memang dihasilkan ketika operasi pemotongan, namun ketika sedang dalam kondisi idling-pun, intensitas kebisingan yang dihasilkan bisa mencapai $95 \mathrm{dBA}$ (Owoyemi dkk, 2017). Intensitas kebisingan yang dihasilkan oleh mesin gergaji kayu dapat dipengaruhi oleh beberapa faktor seperti yang disajikan pada tabel 2.

Tabel 2. Faktor yang Mempengaruhi Emisi Kebisingan

\begin{tabular}{|c|c|c|}
\hline Faktor & Sub faktor & Efek \\
\hline \multirow[t]{5}{*}{ Kayu } & Spesies & $\begin{array}{l}\text { Spesies kayu yang keras dan kaku akan menghasilkan intensitas kebisingan yang } \\
\text { lebih tinggi. }\end{array}$ \\
\hline & Lebar & Kayu yang lebar akan mentransmisikan kebisingan ke area yang lebih luas. \\
\hline & Ketebalan & $\begin{array}{l}\text { Kayu yang tipis biasanya menghasilkan getaran yang lebih besar sehingga intensitas } \\
\text { kebisingan yang dihasilkan lebih tinggi. Ketebalan kayu kurang dari } 20 \mathrm{~mm} \text { dapat } \\
\text { meningkatkan intensitas kebisingan secara signifikan. }\end{array}$ \\
\hline & Panjang & $\begin{array}{l}\text { Kayu yang panjang mentransmisikan kebisingan lebih jauh sehingga dapat } \\
\text { mencapai operator. }\end{array}$ \\
\hline & $\begin{array}{l}\text { Tingkat } \\
\text { Kelembaban }\end{array}$ & Kayu yang kering lebih rapuh dan lebih baik dalam mentransmisikan kebisingan. \\
\hline \multirow[t]{4}{*}{$\begin{array}{l}\text { Perkakas/ } \\
\text { Peralatan }\end{array}$} & $\begin{array}{l}\text { Lebar } \\
\text { Pemotong }\end{array}$ & $\begin{array}{l}\text { Intensitas kebisingan tepat di atas pemotong meningkat sebanding dengan lebar } \\
\text { pemotong. Semakin lebar pemotong, intensitas kebisingan semakin meningkat. }\end{array}$ \\
\hline & $\begin{array}{l}\text { Ketajaman } \\
\text { Pemotong }\end{array}$ & $\begin{array}{l}\text { Semakin tumpul mata pisau yang digunakan, maka akan semakin banyak usaha dan } \\
\text { menimbulkan lebih banyak kebisingan }\end{array}$ \\
\hline & $\begin{array}{l}\text { Permukaan } \\
\text { Pemotong }\end{array}$ & $\begin{array}{l}\text { Semakin tidak rata permukaan pemotong, lebih banyak udara yang terperangkap } \\
\text { selama rotasi sehingga lebih banyak kebisingan yang dihasilkan. }\end{array}$ \\
\hline & $\begin{array}{l}\text { Keseimbangan } \\
\text { Kecepatan }\end{array}$ & $\begin{array}{l}\text { Kebisingan akan meningkat seiring dengan meningkatnya kecepatan alat. Alat yang } \\
\text { tidak seimbang dan bergetar akan menimbulkan lebih banyak kebisingan. }\end{array}$ \\
\hline \multirow{2}{*}{$\begin{array}{l}\text { Pengaturan } \\
\text { mesin }\end{array}$} & Kontrol kayu & Semakin bebas kayu bergetar/bergerak, semakin besar tingkat kebisingannya \\
\hline & $\begin{array}{l}\text { Penopang } \\
\text { kayu }\end{array}$ & $\begin{array}{l}\text { Penopang kayu harus diletakkan sedekat mungkin dengan titik pemotongan, jika } \\
\text { sebaliknya maka kebisingan akan semakin meningkat }\end{array}$ \\
\hline Ekstraksi & $\begin{array}{l}\text { Kecepatan } \\
\text { udara }\end{array}$ & $\begin{array}{l}\text { Resonansi dapat menyebabkan intensitas kebisingan yang tinggi. Turbulensi yang } \\
\text { berlebihan dapat meningkatkan kebisingan secara substansial. }\end{array}$ \\
\hline
\end{tabular}

Sumber: Owoyemi dkk, 2017

Intensitas kebisingan pada saat jam istirahat berkisar antara 68,2 - 101,0 dBA. Sumber kebisingan pada saat jam istirahat adalah mesin truk pengangkut kayu dan alat pengasah gergaji. Kebisingan tertinggi pada saat jam istirahat yakni 101,0 dBA tepat berada pada lokasi parkir truk pengangkut kayu, sedangkan kebisingan tertinggi yang dihasilkan oleh mesin pengasah gergaji hanya mencapai $87,9 \mathrm{dBA}$ dan hanya sampai radius 2 meter dari alat. Luas area dengan intensitas kebisingan di atas NAB kurang dari 30 $\mathrm{m}^{2}$. Berdasarkan hasil observasi peneliti pada saat jam istirahat, diketahui bahwa sebagian besar responden tidak berada pada lokasi dengan kebisingan tinggi. Hanya terdapat tiga responden yang berada pada area dengan intensitas 
kebisingan tinggi yakni satu orang supir truk, satu orang pekerja pengangkut (kayu ke dalam truk), dan satu orang operator mesin pengasah gergaji. Hasil penelitian ini sejalan dengan yang diutarakan oleh Owoyemi dkk. (2017), bahwa sumber utama kebisingan yang terkait dengan operasi penggergajian juga dapat meliputi kegiatan transportasi serta kegiatan pembongkaran dan pemuatan kayu gelondongan ke dalam truk.

\section{Penentuan Noise Reduction Rating Alat Pelindung Telinga}

Apabila pengendalian kebisingan berupa langkah-langkah pengurangan kebisingan sudah tidak memungkinkan lagi, perlu dipastikan perlindungan bagi pekerja yang terpapar kebisingan di atas NAB. Ini dapat dilakukan, misalnya, dengan merekomendasikan pemakaian earplug (penutup telinga) atau earmuff (penutup telinga) (Owoyemi dkk, 2017). Penggunaan APT bertujuan untuk meminimalisir dampak keluhan pendengaran maupun non-pendengaran yang dialami oleh pekerja akibat paparan kebisingan di atas NAB yang umumnya terdapat pada tempat kerja. APT akan efektif melindungi pekerja apabila penggunaannya sesuai dengan kondisi bahaya yang ada di tempat kerja yang dalam hal ini adalah intensitas kebisingan. Hal ini berarti, APT yang dipilih untuk melindungi pekerja harus memiliki daya redam kebisingan yang cukup. Dengan kata lain, APT harus dapat mereduksi kebisingan yang sampai ke telinga pekerja sampai dengan di bawah NAB.

Ukuran yang menggambarkan kemampuan suatu APT untuk mengurangi atau meredam tingkat kebisingan disebut dengan istilah noise reduction rate (NRR). Semakin tinggi NRR suatu APT, maka semakin besar kebisingan yang dapat direduksi oleh APT tersebut (Sari, 2009). NRR biasanya tercantum dalam kemasan, lael atau manual APT. Nilai NRR sangat dipengaruhi oleh jenis dan bahan APT itu sendiri, sehingga nilai NRR harus terlebih dahulu dihitung untuk dapat menentukan jenis dan bahan APT yang tepat untuk melindungi pekerja. NRR dapat diukur dengan persamaan berikut :

$N R R=($ Tingkat Reduksi Kebisingan $\times 2)+7$
NRR APT yang direkomendasikan berdasarkan paparan intensitas kebisingan yang tertera pada peta intensitas kebisingan disajikan pada tabel 3 berikut.

Tabel 3. NRR APT yang Direkomendasikan sesuai Intensitas Kebisingan Di Area Kerja UD. Mayoa

\begin{tabular}{|c|c|c|c|}
\hline $\begin{array}{c}\text { Intensitas } \\
\text { Kebisinga } \\
\text { n (dBA) }\end{array}$ & $\begin{array}{c}\text { Tingkat } \\
\text { Reduksi } \\
\text { Kebisinga } \\
\text { n (dBA) }\end{array}$ & $\begin{array}{c}\text { NR } \\
\mathbf{R}\end{array}$ & $\begin{array}{c}\text { Jenis dan } \\
\text { Bahan APT }\end{array}$ \\
\hline $86-90$ & $1-5$ & $9-17$ & $\begin{array}{l}\text { Sumbat } \\
\text { telinga } \\
\text { (molded } \\
\text { plugs/foam } \\
\text { plugs) }\end{array}$ \\
\hline $91-95$ & $6-10$ & $19-27$ & $\begin{array}{l}\text { Sumbat } \\
\text { telinga (foam } \\
\text { plugs) }\end{array}$ \\
\hline $96-100$ & $11-15$ & $29-37$ & $\begin{array}{l}\text { Sumbat } \\
\text { telinga (foam } \\
\text { plugs) / } \\
\text { Tutup telinga }\end{array}$ \\
\hline $101-105$ & $16-20$ & $39-47$ & $\begin{array}{l}\text { Sumbat } \\
\text { telinga dan } \\
\text { tutup telinga } \\
\text { serta } \\
\text { pemberlakua } \\
\text { n pembatasan } \\
\text { jam kerja }\end{array}$ \\
\hline$>105$ & $>21$ & $<49$ & $\begin{array}{l}\text { Sumbat } \\
\text { telinga dan } \\
\text { Tutup telinga } \\
\text { serta } \\
\text { pemberlakua } \\
\text { n pembatasan } \\
\text { jam kerja }\end{array}$ \\
\hline
\end{tabular}

Pada saat seorang pekerja terpapar kebisingan tinggi, terutama untuk paparan 8 jam yang reratanya intensitas kebisingannya lebih dari 105 $\mathrm{dBA}$, atenuasi satu perangkat APT mungkin saja tidak memadai. Pada kasus seperti ini, dibutuhkan perlindungan pendengaran ganda yakni sumbat telingan dan penutup telinga secara bersama-sama (Berger, 1983). Perlindungan pendengaran ganda dapat menambah daya redam $5 \mathrm{dBA}$ dari nilai NRR. Dalam hal pekerja harus menggunakan perlindungan ganda, maka penggunaan sumbat telinga bertali dan berpita (head band) harus dihindari karena dapat mengganggu penutup telinga sehingga penutup telinga tidak dapat menutupi telinga dengan sempurna (OSHA, 2013). 


\section{KESIMPULAN DAN SARAN}

\section{Kesimpulan}

Berdasarkan hasil dan pembahasan penelitian, dapat ditarik kesimpulan bahwa sebagian besar responden mengalami keluhan pendengaran pada level yang tidak mengganggu aktifitas. Pemetaan intensitas kebisingan menunjukkan bahwa kebisingan yang terjadi pada saat jam kerja berkisar antara 73,8 - 105,2 dBA dan luas area dengan tingkat kebisingan di atas NAB adalah sekitar $500 \mathrm{~m}^{2}$. Intensitas pada saat jam istirahat berkisar antara 68,2 - 101,0 $\mathrm{dBA}$ dengan luas area dengan tingkat kebisingan di atas NAB adalah kurang dari $30 \mathrm{~m}^{2}$. APT yang direkomendasikan untuk tingkat kebisingan 86 $95 \mathrm{dBA}$ adalah sumbat telinga, untuk kebisingan $96-100 \mathrm{dBA}$ adalah sumbat telinga/penutup telinga, sedangkan untuk kebisingan lebih dari 100 dBA adalah perlindungan ganda yakni sumbat telinga dan penutup telinga.

\section{Saran}

Saran yang dapat diberikan kepada pengurus tempat kerja adalah mengingat eliminasi, substitusi, dan pengendalian teknik kurang memungkinkan untuk dilakukan utamanya karena alasan ketebatasan modal, maka peneliti upaya pengendalian bahaya kebisingan yang memungkinkan untuk dilakukan adalah secara administratif yakni dengan cara redesain jam kerja atau penerapan rotasi kerja. Pengendalian secara administrative perlu didukung dengan penerapan penggunaan APT berupa sumbat telingan dan/atau penutup telinga pada pekerja yang disesuaikan dengan tingkat kebisingan di area kerja.

\section{DAFTAR RUJUKAN}

1] Berger, E.H. (1983). Laboratory Attenuation of Earmuffs and Earplugs Both Singly and in Combination. m. Ind. Byg. Assoc. J, 44(5), 321-329.

2] Dhere, A.M., Pawar, C.B., Patil, D.A., Pawar, J.A. (2009) Noise induced hearing loss (NIHL) in saw mill and printing press workers in Akluj Town of Solapur district. J. Environ. Sci. Eng. 51, 187-190.

3] Fahlefi, A.M. (2020). Intensitas Kebisingan dan Keluhan Pendengaran pada Pekerja Penggergaji Kayu Kabupaten Jember. Skripsi. Universitas Jember
4] Gani, L.R., Rachmawati, D.A., Indreswari, L., Mardijana, A., Nurdian, Y. (2020). Hubungan antara Kebisingan di Tempat Kerja dengan Kualitas Tidur pada Pekerja Pabrik Kayu PT. Muroco Jember. Journal of Agromedicine and Medical Sciences, 4(2), 72-76.

5] Gokulram, M. Prabu, M. Magibalan, S. Boopathi, R. Senthilkumar, P. (2017). A Review on Noise Mapping. JETIR, 4(10), 541-544.

6] Keputusan Menteri Lingkungan Hidup No. KEP-48/MENLH/11/1996 tentang Baku Tingkat Kebisingan

7] Lie, A., Skogstad, M., Johannessen H.A., Tynes, T., Mehlum, I.S., Nordby, K.C., Engdahl, B., Tambs, K. (2016). Occupational Noise Exposure and Hearing: a Systematic Review. Int Arch Occup Environ Health, 82, 351-372.

8] Noweir M.H., Bafail, A.O., Jomoah, I.M. (2015). Noise Pollution in Metalwork and Woodwork Industries in the Kingdom of Saudi Arabia. International Journal of Occupational Safety and Ergonomics, 20(4), 661-670

9] OSHA. $2015 . \quad$ URL https://www.osha.gov/dts/osta/otm/new noi sel. Accessed November 30 2020.

10] Owoyemi, M.J., Falemara, B.C., Owoyemi, A.J. 2017. Noise Pollution and Control in Wood Mechanical Processing Wood Industries. Biomedical Statistics and Informatics. 2(2), 54-60.

11] Platon, S.N., Hionis C.A. (2014). Noise Exposure Risk Prevention In Working Environment Using Noise Mapping. Environmental Engineering and Management Journal, 13(6), 1349-1354

12] Robinson, T., Whittaker, J., Acharya, A., Singh, D., Smith, M. (2015). Prevalence of noise-induced hearing loss among woodworkers in Nepal: A pilot study. Int. J. Occup. Environ. Health, 21(1), 14-22.

13] Samelli, A.G., Andrade, C.Q., Pereira, M.B., Matas C.G. (2013). Hearing Complaints and the audiological profile of the users of an academic health center in the western region of São Paulo. Int Arch Otorhinolaryngol, 12(2), 125-130. 
21 Ikesma: Jurnal Ilmu Kesehatan Masyarakat, Vol. 17, No. 1 Maret 2021, 14-21

14] Sari, A.Y. (2009). Pemantauan Kebisingan dan Efektifitas Pengendalian yang Ada di Dapur Peleburan Baja Slab Steel Plant II (SSP II) PT Krakatau Steel Cilegon. Laporan Khusus. Universitas Sebelas Maret

15] SNI 7231:2009 tentang Metoda Pengukuran Kebisingan di Tempat Kerja

16] WHO. 2018. Addressing the Rising Prevalence of Hearing Loss. URL https://apps.who.int/iris/bitstream/handle/10 665/260336/9789241550260-eng.pdf. Accessed November $30^{\text {th }} 2020$.

17] Zheng, Y.P., Juang, Y.J., Yiin, L.M. (2020). Modeling of Woodworkers' Exposure to Occupational Noises by Integrating Frequency Spectra Generated by Power Tools: A Pilot Study. Applied Sciences, 10, 1-8. 